\title{
Is Vitamin D Supplementation Protective against Coronavirus Disease 2019 (COVID-19)?
}

\author{
Hubert Mado ${ }^{1 \star}$, Edyta Reichman-Warmusz ${ }^{1}$, Damian Dudek ${ }^{1}$, Oliwia Warmusz ${ }^{1}$
}

${ }^{1}$ Department of Histology and Cell Pathology in Zabrze, Medical University of Silesia in Katowice. Jordana Street 19, 41-808 Zabrze, POLAND *Corresponding Author: hubert.mado@med.sum.edu.pl

Citation: Mado H, Reichman-Warmusz E, Dudek D, Warmusz O. Is Vitamin D Supplementation Protective against Coronavirus Disease 2019 (COVID-19)?. Electron J Gen Med. 2021;18(2):em283. https://doi.org/10.29333/ejgm/9762

\section{ARTICLE INFO}

Received: 1 Jan. 2021

Accepted: 27 Feb. 2021

\begin{abstract}
Vitamin D, through various mechanisms, affects the immune system, resulting in antiviral effects. Recent studies have also shown that it is effective and safe in the prevention of acute respiratory infections. For this reason, in the era of Coronavirus Disease 2019 pandemic (COVID-19), it is speculated whether vitamin D may also have a positive effect in the course of COVID-19. However, the results of available studies are contradictory, although due to the safety of vitamin D, as well as the information known so far, its regular supplementation in people at risk of deficiency seems to be reasonable.
\end{abstract}

Keywords: vitamin D, coronavirus disease 2019, COVID-19, SARS-CoV-2, acute respiratory infections

\section{INTRODUCTION}

In recent years there have been a number of publications suggesting that vitamin D supplementation may prevent acute respiratory infections (ARIs) [1]. This was thought to be related, among other things, to the fact that during the winter seasons when vitamin D levels are reduced in the population there is an increased frequency of viral infections [2]. Potential mechanisms that would explain these beneficial effects of vitamin $D$ would include, for instance, its ability to activate peptides secreted on the surface of mucous membranes, which consequently show antiviral and antibacterial properties [3]. However, the results of further studies on the importance of vitamin D supplementation in the prevention of ARIs were contradictory [1]. Afterwards, however, a large meta-analysis was able to show that regular vitamin $\mathrm{D}$ supplementation (but not large bolus doses of vitamin D) does indeed show a prophylactic effect against ARIs, and yet is safe [4]. Due to this, it has been speculated that vitamin D supplementation may also protect against Coronavirus Disease 2019 (COVID-19).

\section{Mechanisms of the Hypothetical Prophylactic Effect of Vitamin D}

It is important to outline the mechanisms of vitamin $D$ action that may support this hypothesis. Vitamin D strengthens the first line of defense of the human organism which is the innate immune system. This is done through induction of antimicrobial peptides such as cathelicidin, which in turn leads to destruction and removal of viruses, stimulation of recruitment of neutrophils, monocytes/macrophages and dendritic cells, which also kill and remove pathogens, and through initiation of adaptive immune responses [5-13]. This phenomenon was first observed when it was shown that, under the influence of an intracellular infection (Mycobacterium tuberculosis), there was intracellular synthesis by monocytes or macrophages of the active form of vitamin $D\left(1,25(\mathrm{OH})_{2} \mathrm{D}\right)$, which ultimately resulted precisely in the synthesis of cathelicidin, and consequently in the intracellular killing of microorganisms [5,9,14-15]. Importantly, the ability of macrophages to synthesize cathelicidin has been shown to be related to plasma 25-OHD levels [5,15-16]. A similar phenomenon was also observed in epithelial tissue [5-7]. Cathelicidin exerts its numerous effects through induction of pro-inflammatory cytokines, stimulation of chemotaxis and promotion of removal of respiratory pathogens by induction of apoptosis and autophagy of infected epithelial cells [5-7].

Vitamin $D$ has its beneficial effect on the innate immune system also through other mechanisms, as through stimulation of $\beta$-defensin 2 synthesis, whose profile of action is similar to that presented by cathelicidin $[9,17-18]$. In general, it can be put that the presented antimicrobial mechanisms are largely related to the induction of autophagy [5,7]. Antimicrobial effects are also induced by reducing intracellular iron levels in a hepcidin-dependent mechanism [19-20]. Although this information explains why low vitamin D levels are associated with more frequent respiratory infections, the mechanisms described are rather those related to antibacterial protection [21]. Nevertheless, vitamin D may exert a number of strictly viral effects that overlap to some extent with antimicrobial mechanisms [5,22]. Both the mechanism through cathelicidin and $\beta$-defensin 2 involve inhibition of the ability of the virus to enter cells and replicate [11-12]. The most key effect in this process, however, seems to be the induction of autophagy, as it has been shown that this is how the vitamin can reduce infection with influenza A, HIV-1, rotavirus and hepatitis C (Figure 1) [5,10,13,23-29]. 


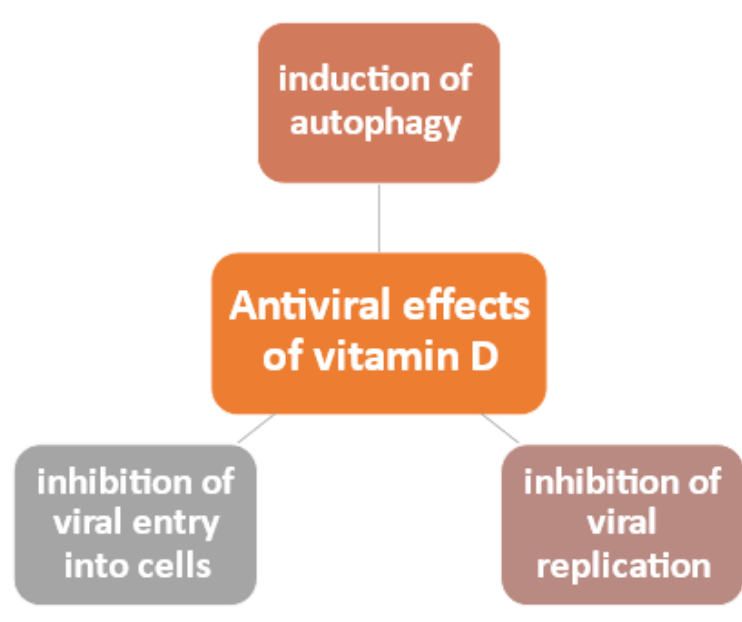

Figure 1. Basic antiviral effects of vitamin D

This induction of autophagy may be dependent on plasma 25-OHD levels [5,22]. Both 25-OHD and the active form of vitamin D increase the expression of the autophagy marker LC3 $[5,7,22,29]$. The enhancement of autophagy and consequently the antiviral effect by vitamin $D$ is the effect of increasing the synthesis of Beklin-1 and PI3KC3, which are essential enzymes in increasing autophagy, and is also the effect of inhibiting the mTOR pathway, which suppresses autophagy [5,30-32]. Vitamin D may also promote autophagy by stimulating the formation of autophagosomes, and also to maximize the antiviral effect play an important role in maintaining an appropriate balance between apoptosis and autophagy $[5,7,25]$. It is worth mentioning that in acute conditions, activation of the innate immune response is beneficial, however, if this activation is chronic it can be the cause of a cytokine storm (and as is known, the cytokine storm is devastating aspect in the pathophysiology of COVID-19) [5]. An active form of vitamin $D$ counteracts this chronic activation of the innate immune response, which is done by downregulating toll-like receptors (TLR) and also by inhibiting interferony (INF- $\gamma$ ) and TNF/NF-KB signaling pathways [5]. Vitamin $D$, in addition to initiating an adaptive immune response, also prevents an uncontrolled immune response, which could also be harmful. In this case, $1,25(\mathrm{OH})_{2} \mathrm{D}$ exerts this effect by, among other things, inhibiting the maturation of dendritic cells and also by altering the profile of $\mathrm{T}$ lymphocytes from pro-inflammatory Th1 and Th17 to anti-inflammatory Th2 and Treg, in effect again helping to prevent a cytokine storm [5,33-36].

\section{State of Current Research}

It is therefore already known that hypothetically vitamin D could have a prophylactic effect against COVID-19 (Figure 2). In any case, at the moment we lack cohort and clinical studies that could clearly define the role of the vitamin in the prevention of COVID-19, but there are retrospective studies. D'Avolio et al. demonstrated that patients with PCR-confirmed SARS-CoV-2 infection have significantly lower plasma 25(OH)D levels than those with negative results [37]. Rhodes et al. in their study shows an indirect relationship between vitamin $D$ levels and COVID-19 severity [38]. Namely, it was shown that there is a $4.4 \%$ increase in COVID-19 mortality for every 1 degree north of latitude 28 degrees, and these results were adjusted for age [38]. Also in another study, a similar relationship was shown by observing that the northern states of the United States, i.e. above Latitude 40, have a higher mortality rate due to COVID-19 than the southern states [39]. This may therefore suggest that UV radiation shows a protective effect against COVID-19, potentially indirectly by increasing vitamin D synthesis. Nevertheless, it should be kept in mind that UV radiation has many vitamin D-independent effects that could potentially explain such a relationship, for example, suppression of T-lymphocyte activation in the skin $[1,40]$. As mentioned before, only preliminary and retrospective information is available. However, the available studies, although contradictory, often indicate that the course of COVID-19 may be related to vitamin D deficiency, and the fact that vitamin $D$ deficiency hypothetically could be a risk factor for COVID-19 and its unfavorable outcomes may explain the extraskeletal effects of vitamin D on the immune system $[5,41]$. For example, a cohort observation by Tan et al. indicates that patients receiving vitamin $D$ (as well as magnesium and vitamin

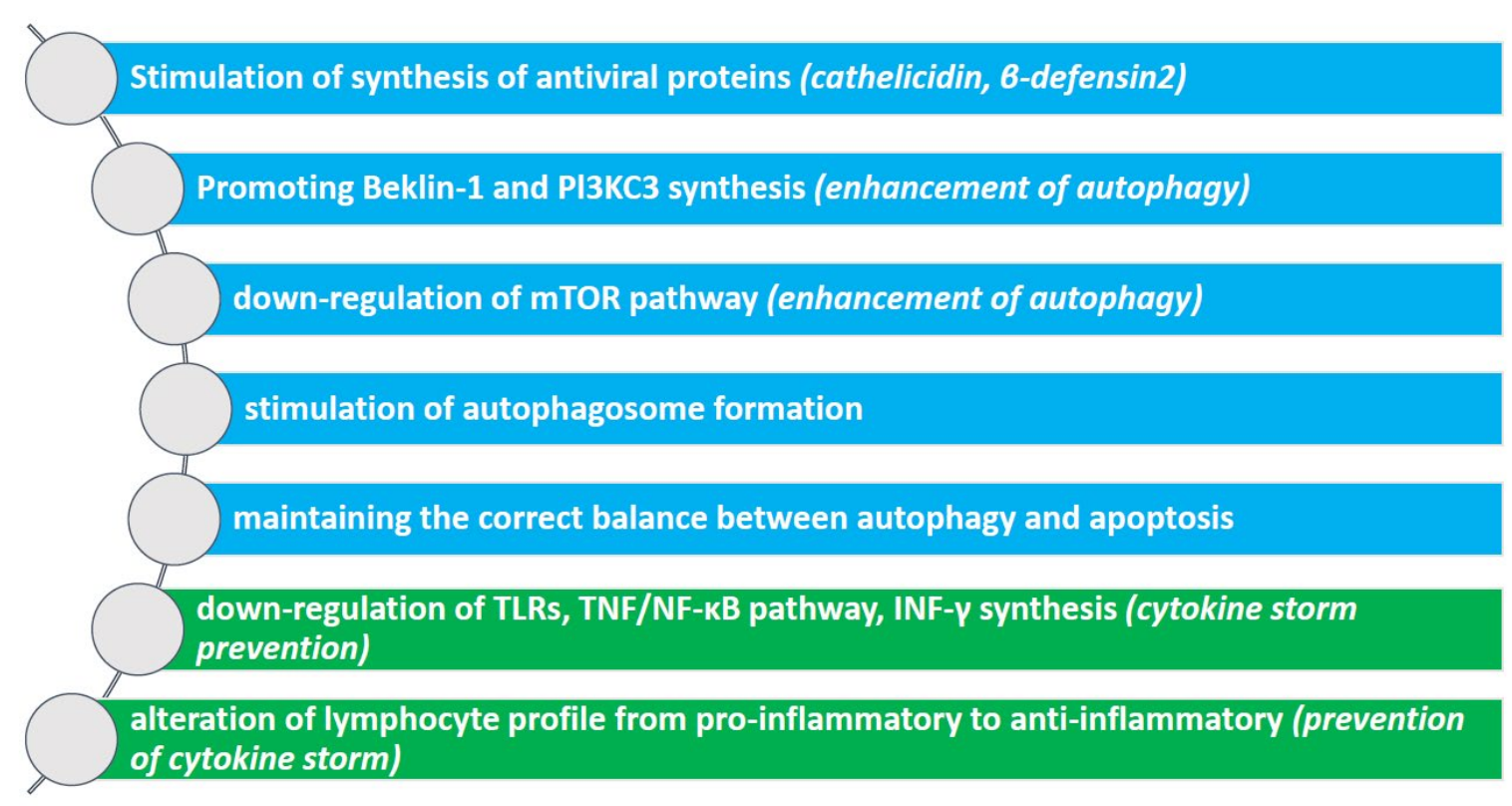

Figure 2. Summary of vitamin D effects that may be potentially beneficial against COVID-19 
B12) shows a significant protective effect against clinical deterioration in the course of COVID-19, the llie et al. study showed a significantly negative correlation between vitamin $D$ levels and the number of cases and deaths due to COVID-19, while the Ali study observed a similar relationship to the Ilie et al. report, but no negative correlation between vitamin $D$ levels and deaths due to COVID-19 [41-43]. On the other hand, there are also studies that show opposite results [5,41]. Hastie et al. revealed that vitamin $D$ has a significant association with COVID-19 infection, in a univariate analysis, although once covariables are taken into account, such a relationship is no longer observed [44]. Also Darling et al. observed no difference in vitamin D levels between COVID-19 cases and controls [45]. Although the results presented are conflicting, recent studies have consistently shown a more common presence of reduced vitamin D levels in patients with severe forms of COVID-19 [46]. This therefore supports that patients who are at risk of COVID19 infection and/or influenza should consider several weeks of vitamin D supplementation at a safe dose of $10,000 \mathrm{IU} / \mathrm{d}$ to quickly increase $25(\mathrm{OH}) \mathrm{D}$ levels, followed by a dose of 5000 IU/d [46-50].

\section{CONCLUSIONS}

Thus, in conclusion, it is not clear whether vitamin D can show a protective effect against COVID-19 or reduce mortality in its course. The available studies are contradictory and, at the moment, we can only state with certainty that further research on the matter is necessary. Nevertheless, it seems reasonable that, in the era of the COVID-19 pandemic, people at risk of reduced vitamin $D$ levels should be advised to supplement it regularly, which is all the more justified in view of the results of the cited recent meta-analysis that demonstrated the efficacy and safety of vitamin $D$ in preventing ARI.

Author contributions: HM: conceptualization, review of literature analysis of available literature, writing - original draft, writing - review \& editing, conception and creation of figures, corresponding author. ER-W: participation in the review of literature. DD: participation in the review of literature. $\mathbf{O W}$ : participation in the review of literature.

Funding: This paper received no grant from any funding agency in the public, commercial, or not-for-profit sectors.

Declaration of interest: The authors declare that there is no conflict of interest.

\section{REFERENCES}

1. Bergman P. The link between vitamin D and COVID-19: distinguishing facts from fiction. J Intern Med. 2021 Jan;289(1):131-3. https://doi.org/10.1111/joim.13158 PMID:32652766 PMCID:PMC7405052

2. Hyppönen E, Power C. Hypovitaminosis D in British adults at age $45 \mathrm{y}$ : nationwide cohort study of dietary and lifestyle predictors. Am J Clin Nutr. 2007 Mar;85(3):860-8. https://doi.org/10.1093/ajcn/85.3.860 PMID:17344510

3. Hewison M. Antibacterial effects of vitamin D. Nat Rev Endocrinol. $2011 \quad$ Jun;7(6):337-45. https://doi.org/10.1038/nrendo.2010.226
4. Martineau AR, Jolliffe DA, Hooper RL, Greenberg L, Aloia JF, Bergman P, Dubnov-Raz G, Esposito S, Ganmaa D, Ginde et al. Vitamin $D$ supplementation to prevent acute respiratory tract infections: systematic review and meta-analysis of individual participant data. BMJ. 2017 Feb 15;356:i6583. https://doi.org/10.1136/bmj.i6583 PMID:28202713 PMCID: PMC5310969

5. Bilezikian JP, Bikle D, Hewison M, Lazaretti-Castro M, Formenti AM, Gupta A, Madhavan MV, Nair N, Babalyan V, Hutchings N, Napoli N, Accili D, Binkley N, Landry DW, Giustina A. Mechanisms in Endocrinology: Vitamin D and COVID-19. Eur J Endocrinol. 2020 Nov;183(5):R133-R147. https://doi.org/10.1530/EJE-20-0665 PMID: 32755992

6. Greiller CL, Martineau AR. Modulation of the immune response to respiratory viruses by vitamin D. Nutrients. 2015 May 29;7(6):4240-70. https://doi.org/10.3390/ nu7064240 PMID:26035247 PMCID: PMC4488782

7. Yuk JM, Shin DM, Lee HM, Yang CS, Jin HS, Kim KK, Lee ZW, Lee SH, Kim JM, Jo EK. Vitamin D3 induces autophagy in human monocytes/macrophages via cathelicidin. Cell Host Microbe. 2009 Sep 17;6(3):231-43. https://doi.org/10.1016/ j.chom.2009.08.004 PMID:19748465

8. Gombart AF, Borregaard N, Koeffler HP. Human cathelicidin antimicrobial peptide (CAMP) gene is a direct target of the vitamin $D$ receptor and is strongly upregulated in myeloid cells by 1,25-dihydroxyvitamin D3. FASEB J. 2005 Jul;19(9):1067-77. https://doi.org/10.1096/ fj.04-3284com PMID:15985530

9. Wang TT, Nestel FP, Bourdeau V, Nagai Y, Wang Q, Liao J, Tavera-Mendoza L, Lin R, Hanrahan JW, Mader S, White JH. Cutting edge: 1,25-dihydroxyvitamin D3 is a direct inducer of antimicrobial peptide gene expression. J Immunol. 2004 Sep 1;173(5):2909-12. https://doi.org/10.4049/jimmunol. 173.5.2909

10. Campbell GR, Spector SA. Vitamin D inhibits human immunodeficiency virus type 1 and Mycobacterium tuberculosis infection in macrophages through the induction of autophagy. PLoS Pathog. 2012;8(5):e1002689. https://doi.org/10.1371/journal.ppat.1002689 PMID: 22589721 PMCID:PMC3349755.

11. Barlow PG, Svoboda P, Mackellar A, Nash AA, York IA, Pohl $J$, Davidson DJ, Donis RO. Antiviral activity and increased host defense against influenza infection elicited by the human cathelicidin LL-37. PLoS One. 2011;6(10):e25333. https://doi.org/10.1371/journal.pone.0025333 PMID: 22031815 PMCID:PMC3198734

12. Ahmed A, Siman-Tov G, Hall G, Bhalla N, Narayanan A. Human Antimicrobial Peptides as Therapeutics for Viral Infections. Viruses. 2019 Aug 1;11(8):704. https://doi.org/10.3390/v11080704 PMID:31374901 PMCID: PMC6722670

13. Campbell GR, Spector SA. Autophagy induction by vitamin $D$ inhibits both Mycobacterium tuberculosis and human immunodeficiency virus type 1. Autophagy. 2012 Oct;8(10):1523-5. https://doi.org/10.4161/auto.21154 PMID:22892387 PMCID:PMC3679232

14. Rook GA, Steele J, Fraher L, Barker S, Karmali R, O'Riordan $\mathrm{J}$, Stanford J. Vitamin D3, gamma interferon, and control of proliferation of Mycobacterium tuberculosis by human monocytes. Immunology. 1986 Jan;57(1):159-63. PMID:3002968 PMCID:PMC1453883 
15. Liu PT, Stenger S, Li H, Wenzel L, Tan BH, et al.. Toll-like receptor triggering of a vitamin D-mediated human antimicrobial response. Science. 2006 Mar 24;311(5768):1770-3.

https://doi.org/10.1126/science.1123933 PMID:16497887

16. Adams JS, Ren S, Liu PT, Chun RF, Lagishetty V, Gombart AF, Borregaard N, Modlin RL, Hewison M. Vitamin ddirected rheostatic regulation of monocyte antibacterial responses. J Immunol. 2009 Apr 1;182(7):4289-95. https://doi.org/10.4049/jimmunol.0803736 PMID:19299728 PMCID:PMC2683618

17. Wang TT, Dabbas B, Laperriere D, Bitton AJ, Soualhine H, Tavera-Mendoza LE, et al. Direct and indirect induction by 1,25-dihydroxyvitamin D3 of the NOD2/CARD15-defensin beta2 innate immune pathway defective in Crohn disease. J Biol Chem. 2010 Jan 22;285(4):2227-31. https://doi.org/ 10.1074/jbc.C109.071225 PMID:19948723 PMCID: PMC2807280

18. Kim J, Yang YL, Jang SH, Jang YS. Human $\beta$-defensin 2 plays a regulatory role in innate antiviral immunity and is capable of potentiating the induction of antigen-specific immunity. Virol J. 2018 Aug 8;15(1):124. https://doi.org/10.1186/ s12985-018-1035-2 PMID:30089512 PMCID:PMC6083524

19. Ganz T. Hepcidin--a peptide hormone at the interface of innate immunity and iron metabolism. Curr Top Microbiol Immunol. 2006;306:183-98. https://doi.org/10.1007/3-54029916-5_7 PMID:16909922

20. Bacchetta J, Zaritsky JJ, Sea JL, Chun RF, Lisse TS, Zavala $\mathrm{K}$, et al. Suppression of iron-regulatory hepcidin by vitamin D. J Am Soc Nephrol. 2014 Mar;25(3):564-72. https://doi.org/10.1681/ASN.2013040355 PMID:24204002 PMCID:PMC3935584

21. Chan TY. Vitamin D deficiency and susceptibility to tuberculosis. Calcif Tissue Int. 2000 Jun;66(6):476-8. https://doi.org/10.1007/s002230010095 PMID:10821887

22. Shin DM, Yuk JM, Lee HM, Lee SH, Son JW, Harding CV, Kim JM, Modlin RL, Jo EK. Mycobacterial lipoprotein activates autophagy via TLR2/1/CD14 and a functional vitamin D receptor signalling. Cell Microbiol. 2010 Nov;12(11):164865. https://doi.org/10.1111/j.1462-5822.2010.01497.x PMID:20560977 PMCID:PMC2970753

23. Campbell GR, Spector SA. Toll-like receptor 8 ligands activate a vitamin $D$ mediated autophagic response that inhibits human immunodeficiency virus type 1. PLoS Pathog. 2012;8(11):e1003017. https://doi.org/10.1371/ journal.ppat.1003017 PMID:23166493 PMCID:PMC3499571

24. Campbell GR, Spector SA. Hormonally active vitamin D3 (1alpha,25-dihydroxycholecalciferol) triggers autophagy in human macrophages that inhibits HIV-1 infection. J Biol Chem. 2011 May 27;286(21):18890-902. https://doi.org/ 10.1074/jbc.M110.206110 PMID:21454634 PMCID: PMC3099705

25. Teymoori-Rad M, Shokri F, Salimi V, Marashi SM. The interplay between vitamin D and viral infections. Rev Med Virol. 2019 Mar;29(2):e2032. https://doi.org/10.1002/ rmv.2032 PMID:30614127

26. Abdel-Mohsen MA, El-Braky AA, Ghazal AAE, Shamseya MM. Autophagy, apoptosis, vitamin $D$, and vitamin $D$ receptor in hepatocellular carcinoma associated with hepatitis $C$ virus. Medicine (Baltimore). $2018 \quad$ Mar;97(12):e0172. https://doi.org/10.1097/MD.0000000000010172 PMID: 29561429 PMCID:PMC5895342
27. Khare D, Godbole NM, Pawar SD, Mohan V, Pandey G, et al. Calcitriol [1, 25[OH]2 D3] pre- and post-treatment suppresses inflammatory response to influenza A (H1N1) infection in human lung A549 epithelial cells. Eur J Nutr. 2013 Jun;52(4):1405-15. https://doi.org/10.1007/s00394012-0449-7 PMID:23015061

28. Tian G, Liang X, Chen D, Mao X, Yu J, Zheng P, He J, Huang $Z$, Yu B. Vitamin D3 supplementation alleviates rotavirus infection in pigs and IPEC-J2 cells via regulating the autophagy signaling pathway. J Steroid Biochem Mol Biol. 2016 Oct;163:157-63. https://doi.org/10.1016/j.jsbmb. 2016.05.004 PMID:27174720

29. Mushegian AA. Autophagy and vitamin D. Sci Signal. 2017 Mar 21;10(471):eaan2526. https://doi.org/10.1126/ scisignal.aan2526 PMID:28325820

30. Uberti F, Lattuada D, Morsanuto V, Nava U, Bolis G, Vacca G, Squarzanti DF, Cisari C, Molinari C. Vitamin D protects human endothelial cells from oxidative stress through the autophagic and survival pathways. J Clin Endocrinol Metab. 2014 Apr;99(4):1367-74. https://doi.org/10.1210/ jc.2013-2103 PMID:24285680

31. Wang J. Beclin 1 bridges autophagy, apoptosis and differentiation. Autophagy. 2008 Oct;4(7):947-8. https://doi.org/10.4161/auto.6787 PMID:18769161

32. Jang W, Kim HJ, Li H, Jo KD, Lee MK, Song SH, Yang HO. 1,25-Dyhydroxyvitamin $\mathrm{D}_{3}$ attenuates rotenone-induced neurotoxicity in SH-SY5Y cells through induction of autophagy. Biochem Biophys Res Commun. 2014 Aug 15;451(1):142-7.https://doi.org/10.1016/j.bbrc.2014.07.081 PMID:25078626

33. van Etten E, Mathieu C. Immunoregulation by 1,25dihydroxyvitamin D3: basic concepts. J Steroid Biochem Mol Biol. 2005 Oct;97(1-2):93-101. https://doi.org/ 10.1016/j.jsbmb.2005.06.002 PMID:16046118

34. Daniel C, Sartory NA, Zahn N, Radeke HH, Stein JM. Immune modulatory treatment of trinitrobenzene sulfonic acid colitis with calcitriol is associated with a change of a $T$ helper (Th) 1/Th17 to a Th2 and regulatory T cell profile. J Pharmacol Exp Ther. 2008 Jan;324(1):23-33. https://doi.org/10.1124/jpet.107.127209 PMID:17911375

35. Gregori S, Casorati M, Amuchastegui S, Smiroldo S, Davalli AM, Adorini L. Regulatory T cells induced by 1 alpha,25dihydroxyvitamin D3 and mycophenolate mofetil treatment mediate transplantation tolerance. J Immunol. 2001 Aug 15;167(4):1945-53. https://doi.org/10.4049/ jimmunol.167.4.1945 PMID:11489974

36. Rudensky AY. Regulatory T cells and Foxp3. Immunol Rev. 2011 May;241(1):260-8. https://doi.org/10.1111/j.1600065X.2011.01018.x PMID:21488902 PMCID:PMC3077798

37. D'Avolio A, Avataneo V, Manca A, Cusato J, De Nicolò A, Lucchini R, Keller F, Cantù M. 25-Hydroxyvitamin D Concentrations Are Lower in Patients with Positive PCR for SARS-CoV-2. Nutrients. 2020 May 9;12(5):1359. https://doi.org/10.3390/nu12051359 PMID:32397511 PMCID:PMC7285131

38. Rhodes JM, Subramanian S, Laird E, Griffin G, Kenny RA. Perspective: Vitamin D deficiency and COVID-19 severity plausibly linked by latitude, ethnicity, impacts on cytokines, ACE2 and thrombosis. J Intern Med. 2021 Jan;289(1):97-115. https://doi.org/10.1111/joim.13149 PMID:32613681 PMCID:PMC7361294 
39. Marik PE, Kory P, Varon J. Does vitamin D status impact mortality from SARS-CoV-2 infection? Med Drug Discov. 2020 Jun;6:100041. https://doi.org/10.1016/j.medidd.2020. 100041 PMID:32352080 PMCID:PMC7189189

40. Bernard JJ, Gallo RL, Krutmann J. Photoimmunology: how ultraviolet radiation affects the immune system. Nat Rev Immunol. 2019 Nov;19(11):688-701. https://doi.org/ 10.1038/s41577-019-0185-9 PMID:31213673

41. Ali N. Role of vitamin D in preventing of COVID-19 infection, progression and severity. J Infect Public Health. 2020 Oct;13(10):1373-1380. https://doi.org/10.1016/j.jiph.2020. 06.021 PMID:32605780 PMCID:PMC7305922

42. Tan CW, Ho LP, Kalimuddin S, Cherng BPZ, Teh YE, Thien SY, Wong HM, Tern PJW, Chandran M, Chay JWM, Nagarajan C, Sultana R, Low JGH, Ng HJ. Cohort study to evaluate the effect of vitamin D, magnesium, and vitamin B12 in combination on progression to severe outcomes in older patients with coronavirus (COVID-19). Nutrition. 2020 NovDec;79-80:111017. https://doi.org/10.1016/j.nut.2020.111 017 PMID:33039952 PMCID:PMC7832811

43. Ilie PC, Stefanescu S, Smith L. The role of vitamin D in the prevention of coronavirus disease 2019 infection and mortality. Aging Clin Exp Res. 2020 Jul;32(7):1195-8. https://doi.org/10.1007/s40520-020-01570-8 PMID:32377965 PMCID:PMC7202265

44. Hastie CE, Mackay DF, Ho F, Celis-Morales CA, Katikireddi SV, Niedzwiedz CL, Jani BD, Welsh P, Mair FS, Gray SR, O’Donnell CA, Gill JM, Sattar N, Pell JP. Vitamin D concentrations and COVID-19 infection in UK Biobank. Diabetes Metab Syndr. 2020 Jul-Aug;14(4):561-565. https://doi.org/10.1016/j.dsx.2020.04.050

45. Darling A, Ahmadi K, Ward K, Harvey N, Alves A, DunnWalters D, Lanham-New S, Cooper C, Blackbourn D. Vitamin D status, body mass index, ethnicity and COVID-19: Initial analysis of the first-reported UK Biobank COVID-19 positive cases (n 580) compared with negative controls (n 723). 2020; [preprint].
46. Grant WB, Lahore H, McDonnell SL, Baggerly CA, French CB, Aliano JL, Bhattoa HP. Evidence that Vitamin D Supplementation Could Reduce Risk of Influenza and COVID-19 Infections and Deaths. Nutrients. $2020 \mathrm{Apr}$ 2;12(4):988. https://doi.org/10.3390/nu12040988 PMID: 32252338 PMCID:PMC7231123

47. McCullough PJ, Lehrer DS, Amend J. Daily oral dosing of vitamin D3 using 5000 TO 50,000 international units a day in long-term hospitalized patients: Insights from a seven year experience. J Steroid Biochem Mol Biol. 2019 May;189:228-239. https://doi.org/10.1016/j.jsbmb.2018.12. 010 PMID:30611908

48. Malihi Z, Lawes CMM, Wu Z, Huang Y, Waayer D, Toop L, Khaw KT, Camargo CA, Scragg R. Monthly high-dose vitamin $\mathrm{D}$ supplementation does not increase kidney stone risk or serum calcium: results from a randomized controlled trial. Am J Clin Nutr. 2019 Jun 1;109(6):1578-87. https://doi.org/10.1093/ajcn/nqy378 PMID:31005969

49. Amir E, Simmons CE, Freedman OC, Dranitsaris G, Cole DE, Vieth R, Ooi WS, Clemons M. A phase 2 trial exploring the effects of high-dose (10,000 IU/day) vitamin $D(3)$ in breast cancer patients with bone metastases. Cancer. 2010 Jan 15;116(2):284-91. https://doi.org/10.1002/cncr.24749 PMID:19918922

50. Charoenngam N, Shirvani A, Kalajian TA, Song A, Holick MF. The Effect of Various Doses of Oral Vitamin D3 Supplementation on Gut Microbiota in Healthy Adults: A Randomized, Double-blinded, Dose-response Study. Anticancer Res. 2020 Jan;40(1):551-556. https://doi.org/ 10.21873/anticanres.13984 PMID:31892611 